\title{
KLASIFIKASI JENIS KELAMIN PADA CITRA WAJAH MENGGUNAKAN METODE NAIVE BAYES
}

\author{
Rosa Andrie Asmara ${ }^{1}$, Bella Sita Andjani ${ }^{2}$, Ulla Delfana Rosiani ${ }^{3}$, Priska Choirina ${ }^{4}$ \\ 1,2,3,4 Teknik Informatika, Teknologi Informasi, Politeknik Negeri Malang \\ ${ }^{1}$ rosaandrie@gmail.com, ${ }^{2}$ bellasitaandjani@gmail.com, ${ }^{3}$ ullarosi@gmail.com, ${ }^{4}$ priskachoirina17@gmail.com
}

\begin{abstract}
Abstrak
Saat ini perkembangan teknologi yang berkaitan dengan pengenalan wajah banyak dimanfaatkan pada aplikasi pengenalan data biologis (biometrics) seperti pengenalan jenis kelamin. Penerapan aplikasi yang memerlukan pengenalan jenis kelamin adalah proses segmentasi pasar untuk mengetahui trend demografis dari produk yang dipasarkan berdasarkan jenis kelamin. Selain itu, aplikasi ini juga dapat digunakan untuk pembatasan akses suatu ruangan. Klasifikasi jenis kelamin pada citra wajah menggunakan metode Naive Bayes dapat digunakan untuk membedakan wajah wanita dan wajah pria berdasarkan fitur. Pembuatan data training berupa citra wajah dengan total 61 data dengan rincian 25 perempuan dan 36 laki-laki. Penggunaan fitur yang diperoleh dari deteksi mata, hidung dan mulut diekstraksi dengan metode Principal Component Analysis yang selanjutnya akan dilakukan proses klasifikasi jenis kelamin dengan metode Naive Bayes yang menghasilkan akurasi kecocokan sebesar $80 \%$.
\end{abstract}

Kata kunci: jenis kelamin, deteksi wajah, haar cascade classifier, principal component analysis, naive bayes

\section{Pendahuluan}

\subsection{Latar Belakang}

Saat ini perkembangan teknologi yang berkaitan dengan pengenalan wajah banyak dimanfaatkan pada aplikasi pengenalan data biologis (biometrics), pencarian dan pengindeksan database citra dan video digital, keamanan ruangan dan lain-lain. Pemanfaatan data biologis dapat memberikan informasi tentang identifikasi dari setiap individu yang menggunakan ciri-ciri fisik yang dapat membedakan dengan orang lain seperti, suara, wajah, sidik jari ataupun mata. Salah satu pembeda identitas individu yang satu dengan yang lainnya adalah wajah. Contoh informasi yang didapatkan dari wajah adalah umur, karakter, ekspresi dan juga jenis kelamin. Diantara beberapa task kategorisasi wajah, klasifikasi jenis kelamin merupakan informasi yang paling penting secara biologis (Choirina, 2015) .

Klasifikasi merupakan sebuah proses pengelompokam fitur citra pelatihan yang telah disimpan dengan fitur citra uji. Salah satu bagian dari image recognition yang telah dikembangkan saat ini adalah pengenalan jenis kelamin (gender recognition). Kemiripan antara gender recognition dengan face recognition terletak pada proses ekstraksi fiturnya. Namun, sedikit berbeda pada proses pengklasifikasiannya. Kesuliltan dalam proses gender recognition terutama karena kekompleksan dari kondisi wajah, seperti posisi gambar, pencahayaan dan ekspresi gambar yang berbeda-beda yang memiliki dimensi serta reduksi tinggi sehingga harus melalui proses kompresi atau ekstraksi terlebih dahulu sebelum diolah datanya dengan metode klasifikasi.

Penelitian sebelumnya yang terkait dengan penelitian ini adalah penelitian yang dilakukan oleh Priska Choirina. Pada penelitian tersebut deteksi jenis kelamin berdasarkan citra wajah jarak jauh dengan metode Haar Cascade Classifier dapat digunakan untuk membedakan wajah wanita dan wajah pria dengan jarak kurang dari $200 \mathrm{~cm}$. Data yang dilakukan untuk proses training adalah 150 wajah laki-laki dan 150 wajah perempuan, dari jumlah wajah tersebut diambil 100 citra wajah untuk setiap jarak berukuran 100, 150, dan $200 \mathrm{~cm}$. Penggunaan fitur-fitur geometris yang diperoleh dari deteksi mata, hidung dan mulut diproses dengan pengukuran jarak antar fitur-fitur dari wajah yang akan dilakukan proses klasifikasi jenis kelamin. Untuk klasifikasi jenis kelamin dilakukan perbandingan 2 metode klasifikasi yaitu Euclidean Distance dan C4.5 namun pada penelitian tersebut terdapat beberapa masalah diantaranya pada tahap klasifikasi jarak antara tiap fitur tidak presisi serta data set yang kurang bagus sehingga hasil yang diperoleh kurang optimal dikarenakan kurangnya tingkat akurasi pada tahap klasifikasi (Suwandari, 2015)

Algoritma Naive Bayes merupakan sebuah algoritma yang sederhana dengan mengandalkan probabilitas atau peluang, Naive Bayes mudah diimpelemntasikan sebab classifier ini memiliki keuntungan yaitu hanya membutuhkan sejumlah 
kecil data pelatihan untuk hasil uji. Naive Bayes berpotensi cukup bagus dalam mengolah tingkat akurasi sebagai model klasifikasi jenis kelamin . Berdasarkan uraian di atas, maka perlu dibangun aplikasi "Klasifikasi Jenis Kelamin pada citra wajah menggunakan metode Naive Bayes".

\subsection{Rumusan Masalah}

Dengan memperhatikan uraian latar belakang diatas, maka dapat dirumuskan masalah yang terkait, yaitu sebagai berikut :

a. Bagaimana mendeteksi wajah dari citra input menggunakan metode Haar Cascade Classifier?

b. Bagaimana cara ekstraksi fitur citra menggunakan metode Principal Component Analysis?

c. Bagaimana mengklasifikasikan jenis kelamin menggunakan metode Naive Bayes berdasarkan nilai PCA ?

\subsection{Tujuan}

Dari rumusan masalah diatas didapatkan beberapa tujua yaitu :

a. Untuk mengetahui hasil output dari Haar Cascade Classifier dalam mendeteksi wajah .

b. Untuk mengetahui hasil ekstraksi fitur menggunakan metode Principal Component Analysis.

c. Untuk menganalisis hasil tingkat akurasi jenis kelamin dengan metode Naive Bayes.

\subsection{Batasan Masalah}

Dari permasalahan yang telah disebutkan diatas, perlu suatu batasan masalah agar perluasan masalah dapat dihindari yaitu sebagai berikut :

a. Input data berupa citra wajah yang berupa foto menggunakan kamera

b. Metode yang digunakan untuk untuk klasifikasi jenis kelamin mengguunakan metode Naive Bayes

c. Wajah yang digunakan Orang Indonesia

d. Pembuatan data training berupa citra wajah dengan total 61 data dengan rincian 25 Perempuan dan 36 Laki-laki.

e. Pembuatan data training dilakukan dalam kondisi pencahayaan yang cukup.

f. Citra input harus mempunyai 4 fitur yaitu mata kiri, mata kanan, hidung, dan mulut.

\section{Landasan Teori}

\subsection{Biometrik Wajah}

Dalam dunia teknologi informasi, biometric relevan dengan teknologi yang digunakan untuk menganalisa fisik dan kelakuan manusia dalam autentifikasi. Biometrik secara teoritis dapat lebih efektif untuk mengidentifikasikan pribadi seseorang karena biometric mengukur karakteristik masingmasing pribadi untuk membedakan setiap orang. Ketika digunakan untuk indentifikasi pribadi,teknologi biometrics mengukur dan menganalisa karakteristik tingkah laku dan fisiologis manusia. Mengindentifikasi karakteristik fisiologis seseorang yang didasarkan pada pengukuran langsung bagian dari bodyfingertips, hand geometry,facial geometry dan eye retinas serta irises (Choirina, 2015) .

\subsection{Pengenalan Wajah}

Wajah merupakan bagian dari tubuh yang berperan penting dalam proses penyampaian ciri, identitas dan emosi seseorang. Kemampuan manusia dalam mengenali wajah sering terjadi secara tidak sadar, manusia mampu mengenali ribuan wajah sepanjang hidupnya dan mengindentifikasi wajah yang sekilas dikenalnya sampai beberapa tahun kemudian. Proses ini berlangsung begitu cepat dan dapat tersimpan cukup lama dalam memori manusia walaupun wajah yang dikenalnya memiliki banyak perubahan visual seperti adanya perubahan kondisi,ekspresi,sudut pandang,penuaan dan penambahan aksesoris seperti kacamata,topi sampai adanya perubahan gaya rambut.Oleh karena itu wajah digunakan sebagai acuan indikasi untuk mengenali seseorang.Pengenalan wajah merupakan salah satu bagian system biometric yang banyak diaplikasikan khusunya dalam pengklasifikasian jenis kelamin. Identifikasi jenis kelamin dengan citra wajah adalah beberapa aplikasi dari pengenalan wajah. Efisiensi dan akurasi menjadi faktor utama mengapa pengenalan wajah banyak diaplikasikan khusunya dalam system klasifikasi jenis kelamin.

Penelitian terhadap pengenalan wajah manusia sudah banyak dilakukan dengan kelebihan dan kekurangan tertentu, hal ini disebabkan karena wajah manusia merepresentasikan sesuatu yang kompleks dan mengembangkan model komputasi untuk pengenalan wajah manusia adalah hal yang sulit. Pengenalan wajah dibagi menjadi dua bagian yaitu dikenali dan tidak dikenali. Kesulitan muncul ketika wajah dipresentasikan dalam suatu pola yang berisi informasi unik yang membedakan dengan wajah lain. Metode pengenalan wajah memiliki dua prosedur,yaitu :

a. Featured-based yaitu pengenalan kontur wajah dengan mengenali bentuk mata,hidung, dan mulut. Karakteristik organ tersebut kemudian dinyatakan dalam bentuk vector dan vector tersebut terdiri dari bilangan-bilangan yang mewakili baris dan kolom.

b. Image-based yaitu analisis komponen wajah secara keseluruhan. Berdasarkan dari konsep 
ini, perhitungan model terbaik yang menjelaskan bentuk wajah dengan mengutip informasi paling relevan yang terkandung didalam wajah tersebut

\subsection{Deteksi Wajah}

Pendeteksian wajah pada citra merupakan suatu langkah penting menuju interaksi manusia dan computer berbasis visi yang cerdas. Pendeteksian wajah ini merupakan langkah awal dalam berbagai penelitian dibidang pengolahan wajah,termasuk pengenalan wajah,perkiraan pose, dan pengenalan ekspresi. Berbagai teknik telah disulkan untuk mendeteksi wajah didalah sebuah citra mauun video (Choirina, 2015) .

Deteksi wajah adalah langkah awal untuk melakukan identifikasi wajah atau face recognition. Sebuah pendeteksi wajah mampu mengidentifikasi dan menemukan lokasi atau luas semua wajah yang ada didalam sebuah gambar tanpa memperhatikan pose,skala,orientasi,umur, dan ekspresi. Pendeteksian wajah dapat dilakukan dengan memanfaatkan library yang bersifat open source yaitu emguCV. EmguCV adalah bagian dari library open $C V$ yang menggunakan bahasa pemrograman C\#. Proses deteksi adanya citra wajah dalam sebuah gambar pad Open $C V$, menggunakan sebuah metode yang dipublikasikan oleh Paul Viola Michael Jones tahun 2001. Umumnya disebut metode Haar Cascade Classifier.

\subsection{Ekstraksi Fitur}

Ekstraksi fitur citra merupakan tahapan mengekstrak ciri / informasi dari objek di dalam citra yang ingin dikenali/dibedakan dengan objek lainnya. Fitur yang telah diekstrak yaitu mata,hidung,dan mulut yang kemudian digunakan sebagai parameter / nilai masukan untuk membedakan antara objek satu dengan lainnya pada tahapan identifikasi atau klasifikasi.

Eigenface merupakan salah satu metode pengenalan wajah berdasarkan Principal Component Analysis (PCA) yang mudah diimplementasikan. Eigenface dimulai dengan pemrosesan awal untuk mendapatkan hasil citra yang lebih baik. Setelah itu menghitung eigenvector dan eigenvalue dari citra wajah untuk dilakukan proses training image. Proses training wajah yaitu mencari eigenvector, eigenvalue dan average image yang diproyeksikan ke dalam subruang PCA.

\subsection{Kasifikasi Jenis Kelamin}

Klasifikasi merupakan salah satu task analisis data dimana dibentuk sebuah model (classifier) untuk menyatakan suatu objek ke salah satu kategori atau kelas yang sudah didefinisikan sebelumnya. Klasifikasi data merupakan proses yang terdiri atas dua langkah-langkah pertama adalah tahap pelatihan (learning), dimana sebuah algoritma klasifikasi akan membentuk classifier dengan menganalisis atau belajar dari sekumpulan data latih. Pada langkah kedua, model yang terbentuk digunakan untuk mengklasifikasikan data uji. Akurasi dari sebuah classifier untuk sekumpulan data uji yang diberikan merupakan persentase dari data-data uji yang diklasifikasikan dengan benar oleh classifier.

Dari hasil ekstraksi fitur yang nilainya disimpan ke dalam database maka dapat dilakukan klasifikasi berdasarkan nilai-nilai tersebut yang nantinya akan digunakan sebagai acuan untuk data testing. Maka disini dipilih metode Naive Bayes sebagai acuan untuk klasifikasi jenis kelamin.

Bayes merupakan teknik prediksi berbasis probabilitik sederhana yang mendasar pada penerapan teorema Bayes dengan asumsi independensi yang kuat. Dengan kata lain dalam Naïve Bayes, model yang digunakan adalah "model fitur independen". Naive Bayes Classifier merupakan salah satu metode machine learning yang memanfaatkan perhitungan probabilitas dan statistik. Metode ini dikemukakan oleh ilmuwan Inggris yaitu Thomas Bayes untuk memprediksi probabilitas di masa depan berdasarkan pengalaman di masa sebelumnya (Rosiani, 2016).

Algoritma Naive Bayes Classifier merupakan algoritma yang digunakan untuk mencari nilai probabilitas tertinggi untuk mengklasifikasi data uji pada kategori yang paling tepat. Dalam penelitian ini yang menjadi data uji adalah data baru hasil ekstrasi fitur. Ada dua tahap pada klasifikasi jenis kelamin. Tahap pertama adalah pelatihan terhadap fitur yang diketahui kategorinya. Sedangkan tahap kedua adalah proses klasifikasi jenis kelamin yang belum diketahui kategorinya (Modak, 2014) .Berikut adalah proses klasifikasi Naive Bayes :

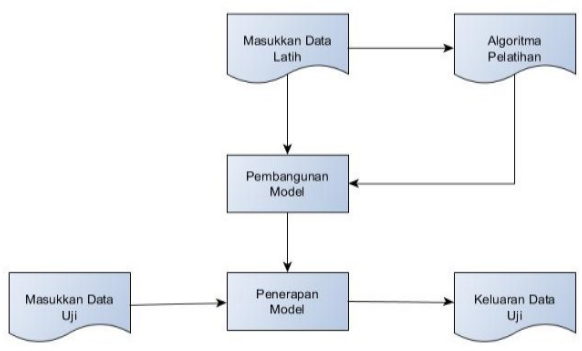

Gambar 1. Proses Klasifikasi Naive Bayes

\section{Metode Penelitian}

\subsection{Metode Pengembangan Sistem}

Dalam tahap pengembangan sistem menggunakan metode pendekatan terstruktur dengan menggunakan model sekuensial linier. Dimana tahapan-tahapan model ini adalah analisis, desain, coding, dan testing. 


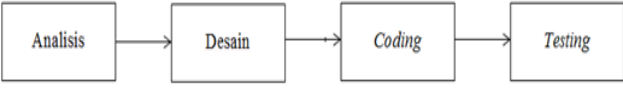

Gambar 2. Metode Pengembangan Sistem

a. Analisis. Tahap analisis adalah tahap pengumpulan informasi yang berkaitan dengan pembangunan sistem pengenalan wajah, baik kebutuhan data,perangkat keras, maupun perangkat lunak. Pada tahap analisis dilakukan pula cara-cara perhitungan metode Eigenface untuk pengenalan wajah.

b. Desain. Setelah tahap analisis selesai dilakukan, selanjutnya adalah tahap desain. Tahap ini merancang model dan alur pembangunan sistem penegnalan wajah sesuai dengan analisis yang telah dilakukan. Proses perancangan desain sangat mempengaruhi proses pembuatan system.

c. Coding. Setelah desain dan alur dirancang, selanjutnya adalah proses implementasi coding. Tahap ini merupakan tahap utama karena pada tahap inilah proses pembangunan system yang dapat menyelesaikan masalah dan mengolah data-data yang terkumpul. Pada tahap ini pula proses hasil desain yang telah dibuat diimplementasikan dalam bentuk kode yang dapat menghasilkan sebuah aplikasi.

d. Testing. Setelah perangkat lunak berhasil dibuat selanjutnya adalah pengujian terhadap system pengenalan wajah menggunakan metode Eigenface. Pengujian dilakukan dengan menguji tingkat akurasi pengenalan wajah pada system yang dibangun.

\subsection{Data}

Komponen yang diperlukan untuk melakukan penelitian ini salah satunya adalah data. Data yang diperlukan sebagai objek pengujian aplikasi ini yaitu, data citra wajah laki-laki dan citra wajah perempuan untuk dilakukan training data dan memiliki format BMP.

\subsection{Metode Pengolahan Data}

Gambar 3 merupakan proses pada aplikasi klasifikasi jenis kelamin pada citra wajah berdasarkan ekstrasi ciri menggunakan Naive Bayes yang terbagi menjadi dua bagian utama yaitu proses training dan proses test.

Pada proses training terdapat beberapa tahap yang dilakukan yaitu Pre-Processing, pendeteksian wajah, ekstrasi fitur wajah dengan Principal Component Analysis (PCA), penyimpanan hasil dari ekstrasi fitur ke dalam penyimpanan dan selanjutnya klasifikasi hasil jenis kelamin dengan Metode Naive Bayes. Proses test sama halnya dengan proses data training perbedaannya adalah nilai yang digunakan untuk pengklasifikasian jenis kelamin berdasarkan nilai yang sudah didapatkan pada data training.

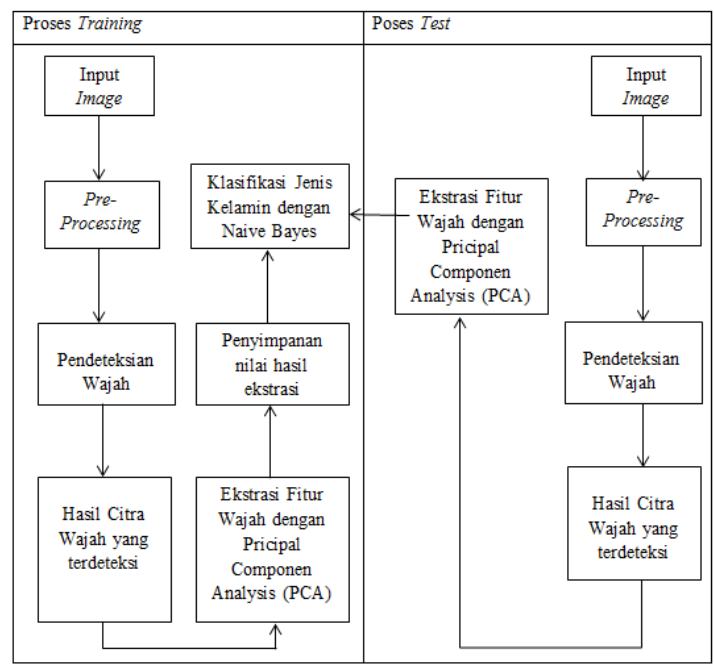

Gambar 3. Metode Pengolahan Data

\section{Analisis Dan Perancangan}

\subsection{Perancangan Sistem}

Secara umum, Blok Diagram dari aplikasi yang akan dibangun ditampilkan pada gambar berikut ini :

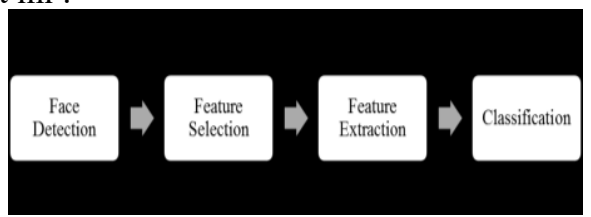

Gambar 4. Perancangan Sistem

- Face Detection. Deteksi wajah berdasarkan jenis kelamin ini menggunakan library EmguCV dengan menggunakan algoritma Haar Cascade Classifier. Didalam metode ini sistem pendeteksian wajah khusus untuk deteksi wajah dengan posisi menghadap kamera (frontal face) sehingga tidak dapat mendeteksi wajah yang bukan dalam posisi tersebut.

- Feature Selection. Pada proses ini dilakukan pemilihan fitur wajah, proses yang dilakukan sama seperti pendeteksian wajah sebelumnya dengan menggunakan library EmguCV. Fiturfitur wajah yang dibutuhkan yaitu mata, hidung, dan mulut.

- Feature Extraction. Ekstrasi Fitur merupakan suatu pengambilan ciri atau fitur dari image yang nantinya akan menghasilkan sebuah nilai berupa matriks kemudian disimpan di database lalu di analisis untuk proses selanjutnya yaitu klasifikasi gender. Ekstraksi fitur disini dibuat dengan bahasa C\# untuk diterapkan pada Metode Principal Component Analysis (PCA). 
Metode tersebut bekerja dengan cara mengurangi jumlah dimensi dari citra masukan dan menangkap variasi total dari citra masukan tersebut yang kemudian direduksi menjadi nilai yang lebih kecil (bilangan real) dibandingkan nilai masukan.

- Classification. Klasifikasi merupakan sebuah proses yang mencocokkan fitur hasil pelatihan citra atau hasil ekstrasi fitur yang telah disimpan dengan fitur citra uji. Klasifikasi disini berupa jenis kelamin yang menggunakan metode Naive Bayes.

\section{Implementasi}

\subsection{Implementasi Proses}

Pada tahap ini akan dilakukan implementasi aplikasi klasifikasi jenis kelamin pada citra wajah menggunakan metode Naive Bayes dengan menggunakan bahasa pemrograman Visual C\#. Dibawah ini merupakan langkah-langkah penggunaan aplikasi tersebut .

Berikut adalah tahapan proses aplikasi :

1. Proses input image $\rightarrow$ pre-processing $\rightarrow$ deteksi wajah

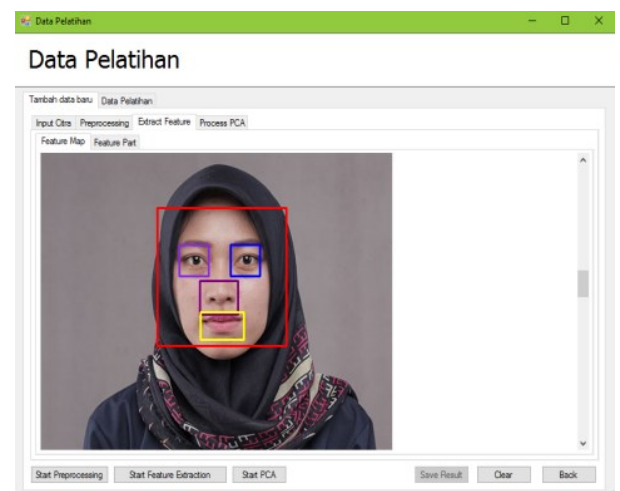

Gambar 5. Proses pendeteksian wajah

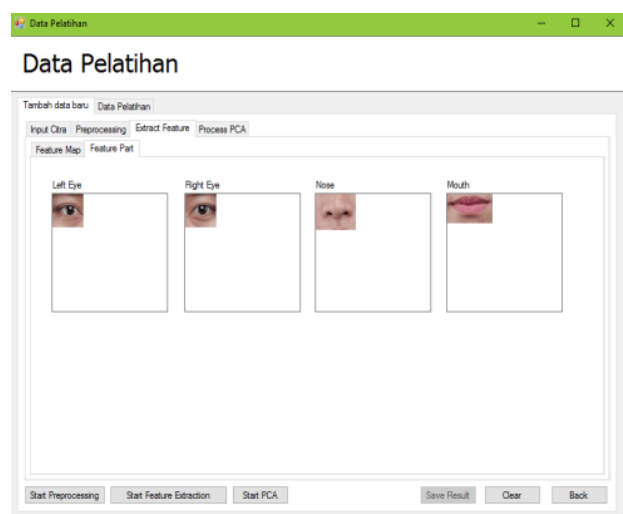

Gambar 6. Proses selection feature

2. Proses ekstraksi fitur dengan metode Principal Component Analysis (PCA)

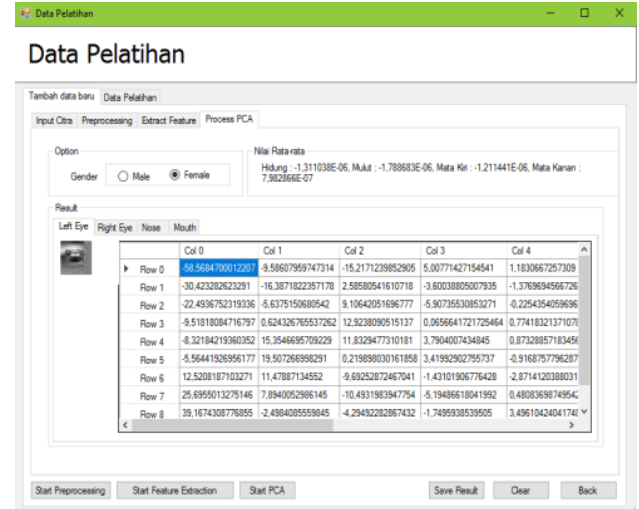

Gambar 7. Proses ekstraksi fitur dengan $P C A$

3. Dan berikut adalah hasil klasifikasi jenis kelamin dengan nilai probabilitas dari proses perhitungan dengan metode Naive Bayes

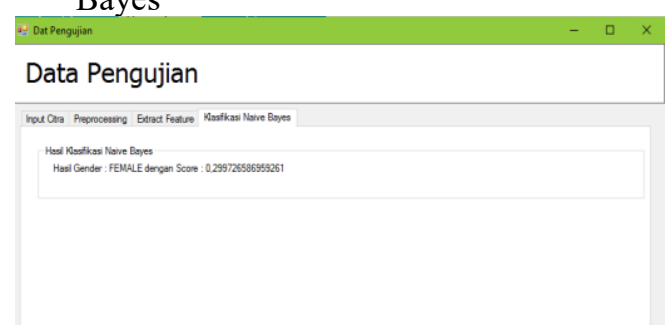

Gambar 8. Proses klasifikasi jenis kelamin dengan Naive Bayes

\subsection{Analisa Hasil Penelitian}

Dari hasil uji coba diatas maka dapat diambil sebuah analisa yaitu semakin banyak data training atau latih maka semakin bagus pula hasil yang didapatkan pada pengujian serta hasil dari tingkat akurasi pada klasifikasi jenis kelamin dengan Metode Naive Bayes .

\section{Pengujian dan Pembahasan}

Setelah melakukan proses training data, untuk melihat apakah aplikasi ini telah berhasil seperti yang diinginkan akan dilakukan pengujian. Pengujian bermaksud untuk mengetahui perangkat lunak yang dibuat sudah memenuhi kriteria yang sesuai dengan tujuan perancangan aplikasi tersebut. Pengujian dilakukan berdasarkan spesifikasi sistem dan pengujian performansi. Pengujian spesifikasi sistem yang dilakukan meliputi pengujian kesesuaian proses, pengujian kesesuaian data dan pengujian tingkat akurasi citra. Pengujian performansi dilakukan dengan serangkaian percobaan-percobaan dalam kondisi tenrtentu yang dapat mempengaruhi hasil dari aplikasi ini.

\subsection{Pengujian performasi}

Dalam proses pengujian performansi ini diantaranya meliputi pengujian pendeteksian input 
wajah dari kamera maupun dari drive, pengujian deteksi wajah serta fitur-fitur wajah dan pengujian ekstraksi fitur wajah. Berikut adalah tabel hasil pengujian ketepatan deteksi wajah terhadap beberapa percobaan dengan jumlah data training yang berbeda:

Tabel 1. Tabel akurasi deteksi wajah

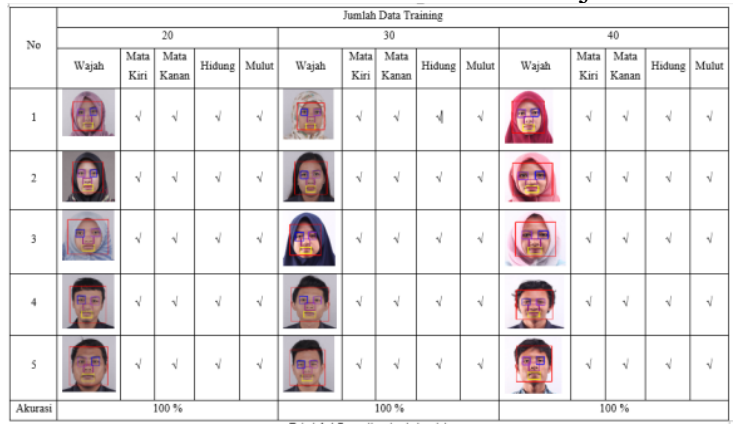

Keterangan :

Tanda " $\sqrt{ }$ " menunjukkan fitur wajah terdeteksi tepat oleh sistem

Tanda "لฟ" menunjukkan fitur tidak terdeteksi tidak tepat oleh system

\section{Kesimpulan dan Saran}

\subsection{Kesimpulan}

Dari hasil penelitian yang telah dilakukan, maka dapat disimpulkan :

a. Proses deteksi wajah menggunakan metode Haar Cascade Clasifier tergolong baik. Hal ini dapat dilihat dari hasil ketepatan pendeteksian pada pengujian dengan hasil sebesar $100 \%$.

b. Tingkat ketepatan deteksi fitur wajah sangat berpengaruh pada klasifikasi jenis kelamin.

c. Proses ekstraksi menggunakan metode Principal Component Analysis sangat berpengaruh pada fitur yang diklasifikasikan.

d. Nilai ekstraksi fitur tergantung pada kualitas gambar.

e. Proses klasifikasi dengan metode Naive Bayes hasilnya cukup akurat untuk mengklasifikasikan jenis kelamin berdasarkan nilai probabilitas yang didapatkan pada setiap gender laki-laki dan perempuan dengan hasil akurasi $80 \%$.

\subsection{Saran}

Berdasarkan penelitian ini, ada beberapa hal yang disarankan yaitu :

a. Untuk ekstraksi fitur dapat ditambahkan jumlah data set, karena semakin banyak data yang dimiliki maka tingkat keakuratannya semakin tinggi.

b. Pada proses klasifikasi dapat digunakan dengan metode jaringan syaraf tiruan dan SVM supada didapatkan akurasi yang lebih baik.

\section{Daftar Pustaka:}

Choirina, Priska.2015. Deteksi jenis berdasarkan citra wajah jarak jauh dengan metode Haar Cascade Classifier Sudi Kasus : Politeknik Negeri Malang

Suwandari, Rizky.2015. Pengenalan Ekspresi Wajah Berdasarkan Ekstrasi fitur menggunakan metode Princpal Component Analysis Studi Kasus : Politeknik Negeri Malang

Rosiani, Ulla D, dkk.2016. Jurnal pendeteksian jenis kelamin pada gambarwajah 2D dengan ekstrasi fitur berbasis Geometri. Jurnal Jurusan Teknologi Informasi Politeknik Negeri Malang

Kholistianingsih, 2012, Identifikasi Wajah Menggunakan Principal Component Analysis Dengan Penambahan Fitur-Fitur Geometris. Purwokerto: Universitas wijayakusuma.

Pramana, Aditya Eka. 2011. Perangkat Lunak Untuk Mengendalikan Pointer Dengan Mata Mengunakan Metode Haar Cascade Dan Eye Tracking. Malang: Universitas Brawijaya.

Modak, Santanu, dkk.2014. A Comparative study of Classifiers' Performance for Gender Classification. India : University of Burdwan 